Hewit,, L. F. (1951). J. gen. Microbiol. 5, 293-297.

\title{
Effect of Cultural Conditions on Bacterial Cytology
}

\author{
By L. F. HEWITT \\ Serum Research Institute (Medical Research Council), Carshalton, Surrey
}

\begin{abstract}
SUMMARY: Phase-contrast microscopy of living bacterial cells under appropriate conditions is of value in determining cellular structure, bacterial nuclear processes, methods of division and the effects of cultural conditions. Different species of bacteria differ in their methods of division (for example by constriction or by cross-septation) and in their apparent internal structure. Considerable differences may be seen also in the same organism grown under different cultural conditions. The same species of bacteria may exist as short oval bacilli in an agar medium and long-chained or filamentous forms in broth, with equally characteristic differences in the distribution of refractile material within the cells. The incorporation of special chemical compounds in the culture medium raises the possibility of vital 'staining' by the deposition of refractile material in defined sites within the bacteria during growth, thus rendering visible by phase-contrast microscopy certain cellular structures in living bacteria. The inclusion in culture media of tellurite and selenite has this effect of showing up internal structure in the bacteria grown in their presence. Apart from the possibility of developing new procedures for detecting internal structure, phase-contrast microscopy is of use in evaluating fixation and staining methods by comparing the fixed and stained specimens with living cells, and thus recognizing distortions and artefacts introduced by preparative treatments.
\end{abstract}

Apart from its purely descriptive value for classification and diagnosis bacterial morphology is being used increasingly for the study of cell structure and physiology. Although this is no recent development (Schaudinn, 1902; Dobell, 1911), advances in technical methods such as those of Badian (1933), Stille (1937) and Piekarski (1937) have led Robinow (1942), Klieneberger-Nobel(1945), and Bisset (1950) to formulate very definite concepts of bacterial structure. The newer methods differ in two principal respects from the older ones which are still used for routine purposes. First, fixation of the organisms is effected, not by drastic heating methods which are likely to cause distortion and shrinkage of the cells, but by gentler methods less likely to cause damage. Secondly, new chemical procedures are introduced into the staining technique in order to demonstrate specific cytological structures such as cell walls and nuclei. Nevertheless, the procedures remain very drastic and include exposure to osmic acid vapour, treatment with cold tannic acid and hot hydrochloric acid, etc. Hence it remains desirable to examine living untreated cells in order to evaluate new procedures and to determine what appearances are in fact vital and which are artefacts. Unfortunately, the electron microscope, which might be of value for this purpose, has several limitations; completely dry specimens must be examined, and because protoplasm is so opaque to electrons chemical treatment is often necessary to reveal many details of internal cellular structure.

Phase-contrast microscopy does not suffer from these particular limitations, moist living cells may be examined under physiological conditions, and it would be anticipated that differences in refractivity might reveal some details of internal cell structure. In the case of Corynebacterium diphtheriae (Hewitt, 
1951) the cytoplasm under suitable conditions appears quite transparent and some details of structure, especially cell walls, are visible, and differences in cultural conditions are reflected in variations in appearance, but a considerable amount of work is required before it can be decided what structures are likely to be visible in the phase-contrast microscope, which techniques are likely to be most useful and whether any developments of methods are likely to be fruitful. Not the least point of value of the method is the possibility of comparing the appearances of living cells with those observed in preparations made by both the older and newer fixing and staining procedures. This communication, therefore, is largely an exploratory one aimed at seeking possible lines of advance and reporting the results obtained so far.

\section{MATERIALS AND METHODS}

The organisms, mostly isolated in the laboratory, were grown in a variety of liquid and solid media of which the composition was varied as described later. Preparations for microscopy were made by modifications of the cover-slip cell method (Hewitt, 1951) and examined with a 2 mm. Cooke, Troughton \& Simms phase-contrast objective.

\section{OBSERVATIONS}

In Pl. 1, figs. 3-5, is seen a great variety of forms of Bacillus cereus which had been grown on a broth agar plate. Some cells are almost uniformly opaque, others contain both opaque and clear patches, whilst still others are almost

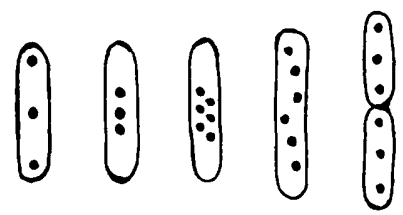

Fig. 1. Refractile granules in B. cereus. completely transparent except for the cell walls and opaque roughly circular inclusions. These circular granules occur frequently in triplets or sextets, and a series may be arranged as in Fig. 1. It is easily possible to postulate that these are nuclear structures with a unit of three chromosomes to each cell and their re-arrangements resemble mitosis. This method of reconstruction is, however, very hazardous and there is no supporting evidence that these granules have any nuclear significance, since cells seen to divide whilst under observation usually have a more refractile appearance. Rearrangement of the dark granules may be observed and the transparent cells may be seen to change rapidly into the refractile type. Sometimes also the refractile cells become transparent with dark granules. Nuclear material in bacterial cells can be demonstrated by Giemsa staining after fixation with osmic acid vapour and hydrolysis with hydrochloric acid (Robinow, 1942), but when Bacillus cereus is treated in this way the dark granules are not stained. This may be seen in Pl. 1, figs. 6, 7 . The cells were stained by this method and then examined by phase-contrast and by ordinary microscopy. The granules which appear dark and highly refractile by phase-contrast are unstained and appear light by ordinary microscopy. It would seem probable that the granules are not nuclear in nature but probably fat-storage depots.

As already mentioned, dividing cells of $\boldsymbol{B}$. cereus are usually almost uniformly 
dark in colour in the phase-contrast microscope but the formation of cross-septa or cell walls can be seen to occur at the point where division afterwards occurs. In Pl. 2, figs. 27-32, are seen serial photographs of a $B$. cereus cover-slip culture at $37^{\circ}$ taken at approximately $45 \mathrm{~min}$. intervals. The formation of cross-septa, the 'thinning' of the protoplasm at this point and constriction of the cells preceding division, are visible.

In some cocci refractile material resembling a central nucleus can be distinguished in living untreated cells (Pl. 2, figs. 11-17) as in specimens stained by methods designed to demonstrate presence of nuclear material (Bisset, 1950). In the case of other organisms, however, no nucleus can be seen by phasecontrast microscopy. Refractile material resembling nuclear or chromatinic structures is very prominent in the Gram-positive bacillus shown in Pl. 3, fig. 34 .

There is a number of different processes of division among the cocci. In some a cross-septum forms as in the diplococci shown in $\mathrm{Pl} .2$, fig. 2, and in the yellow tetrad organism in Pl. 2, figs. 18-21. In the latter case cross-septa at right-angles are formed and so give rise to tetrads. With other cocci such as the haemolytic streptococcus in Pl. 2, fig. 26, and the coccus in Pl. 2, figs. 11-17, the cell elongates and a constriction appears before fission but no cross-septa have been seen. Clear observation of Haemophilus pertussis is difficult owing to the envelope surrounding the organisms; occasionally a structure resembling a cross-septum may be seen in the cell, but it would appear that fission takes place by constriction of the cell. Some evidence of nuclear structure in the cells may be seen in Pl. 2, figs. 22, 23. In staphylococci cross-septa are formed at right angles to one another (Pl. 2, fig. 25).

The effects of cultural conditions on bacterial morphology are very striking. In Pl. 3, figs. 35, 36, are seen cells of Pasteurella pseudotuberculosis isolated from a pancreatic nodule in a guinea-pig and grown in various media. On agar plates (Pl. 3, fig. 35) the organisms are small ovals and almost transparent, whilst in broth (PI. 3, fig. 36) the organisms are longer, contain refractile material at the poles and they remain joined together in long festoons. Presumably the differentiation of refractile material in broth cultures accounts for the commonly observed polar staining of the organisms. In the case of the Gram-positive bacilli seen in Pl. 2, figs. 33, 34, the agar plate cultures are in the form of separate bacilli whilst in broth long filaments are formed and the organisms contain refractile bodies resembling chromatinic structures.

The conclusions of Webb (1949) that magnesium ions are necessary for the fission of bacteria during multiplication are illustrated in Pl. 1, figs. 1, 2, in which cells of Bacillus cereus grown in magnesium-deficient media form long filaments. These filaments contain cross-septa and segments differing in refractive index, some being almost transparent and others deeply refractile but fission of the organisms has not occurred. In Pl. 1, figs. 3-5, are shown the same organism grown in media containing ample magnesium ions and the normal appearance is seen.

In a previous paper it was shown (Hewitt, 1951) that Corynebacterium diphtheriae cultures reduce tellurite and selenite to the elements tellurium and selenium, becoming black or red, and when examined by phase-contrast 
microscopy the cells are seen to contain granules of the elements and refractile deposits in localized sites in the cells. These localized sites resemble nuclear structures and this method of growing organisms in media containing reducible substances which are deposited locally in the cell may constitute a useful means of recognizing nuclei or other cellular structures. In Pl. 1, figs. 8-10, are shown cells of Bacillus cereus grown in the presence of selenite. Some filamentous forms are seen containing cross-septa and refractile patches which may represent nuclear structures. Corynebacterium fascians grown in the prest, $\epsilon_{1}$ ce of selenite is shown in Pl. 3, fig. 37; again dark refractile patches resembling nuclei can be distinguished. It is possible that nuclear material may have an affinity for tellurite and selenite or may be regions of intense metabolic activity where reduction to the element takes place preferentially.

\section{DISCUSSION}

Phase-contrast microscopy of living bacterial cells promises to present new evidence on problems concerning the mechanism of bacterial multiplication and the existence of bacterial nuclei, since possible distortions and artefacts due to fixation and staining procedures are avoided, and actual division of cells may be observed so that speculative reconstruction is unnecessary. It is not yet certain however what cellular structures can be discerned by phase-contrast examination, nor what cultural or preparative method may be effective in demonstrating ordinarily transparent structures.

Differences in the mechanism of fission of the daughter cells during bacterial multiplication (Robinow, 1942; Bisset, 1950) can be seen clearly by phasecontrast methods. Division may occur as in the case of $C$. diphtheriae, by the formation of an easily visible cross-septum and by the daughter-cells bending apart. With other organisms a double cell-wall appears to develop at the point of fission, a constriction appears in the mother-cell at this site, and the daughter cells may remain attached in a chain-like formation. The relative alinement of successive cross-septa accounts for the different groupings of cocci in pairs, tetrads, clusters, etc. When successive cross-septa are parallel, chains may be formed, whilst if they are at right angles tetrads or cubes occur. In magnesiumdeficient media (Webb, 1949) cross-septum formation may be normal but actual fission of the cell is inhibited and long filaments may occur. It is possible that magnesium ions constitute an essential co-enzyme for the final fission process. Other cultural variations also affect the arrangement and appearance of bacterial cells. Frequently when grown on agar plates bacteria may appear as single transparent cells, whilst in broth they may occur as festoons of bacteria containing differentiated refractile patches in the cells.

In some culture media many bacteria appear uniformly transparent by phase-contrast microscopy except for cell walls and food-storage granules, and the latter may be mistaken for nuclear processes, but other organisms appear to possess structures which may well be nuclear, and the incorporation of various chemical substances (such as selenite) in the culture medium may render visible in living cells transparent structures by the localized deposition of refractile material. 
Journal of General Microbiology, Vol. 5, No. 2

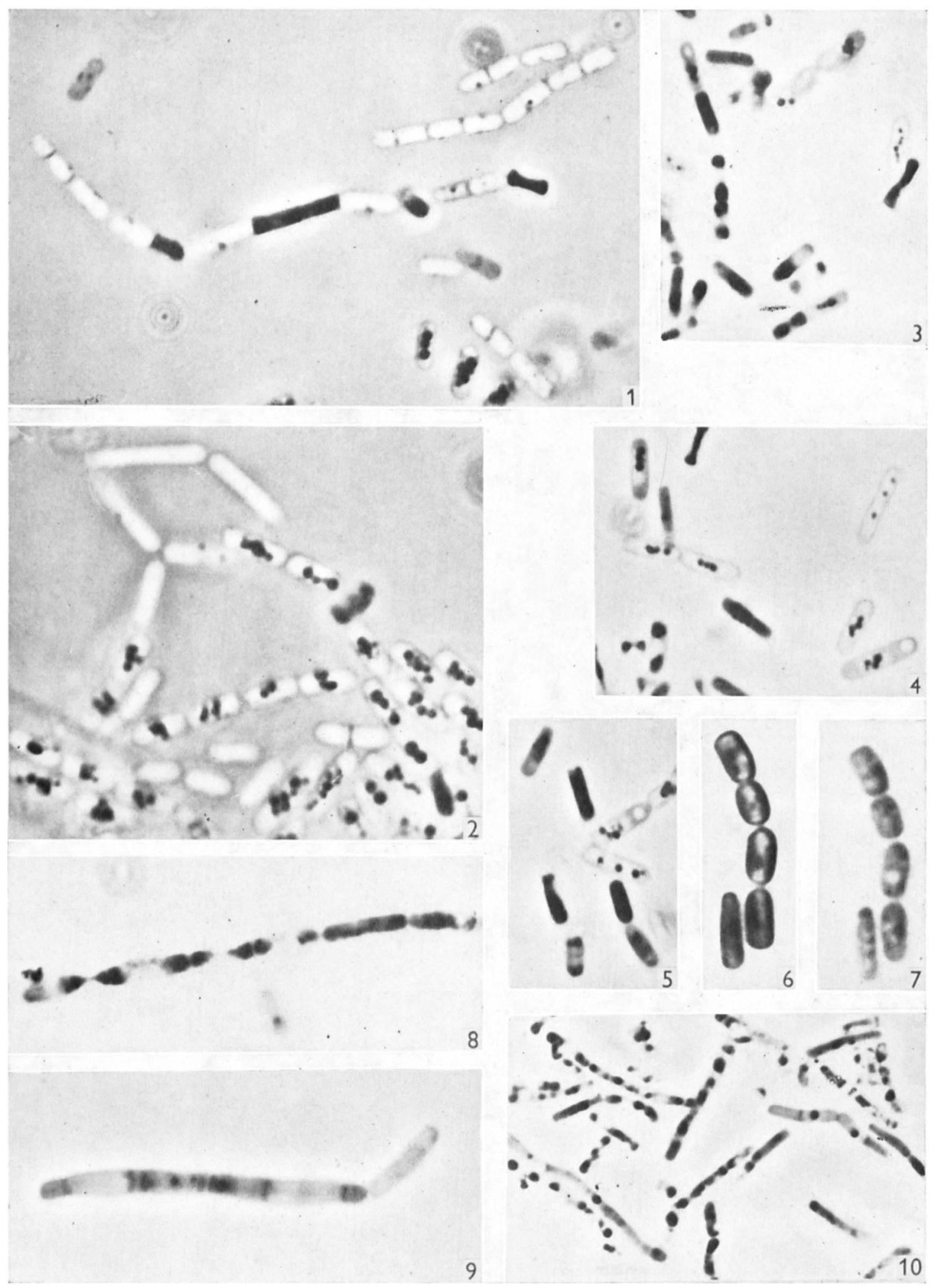

L. F. Hewitt-Bacterial cytology. Plate 1 
Journal of General Microbiology, Vol. 5, No. 2

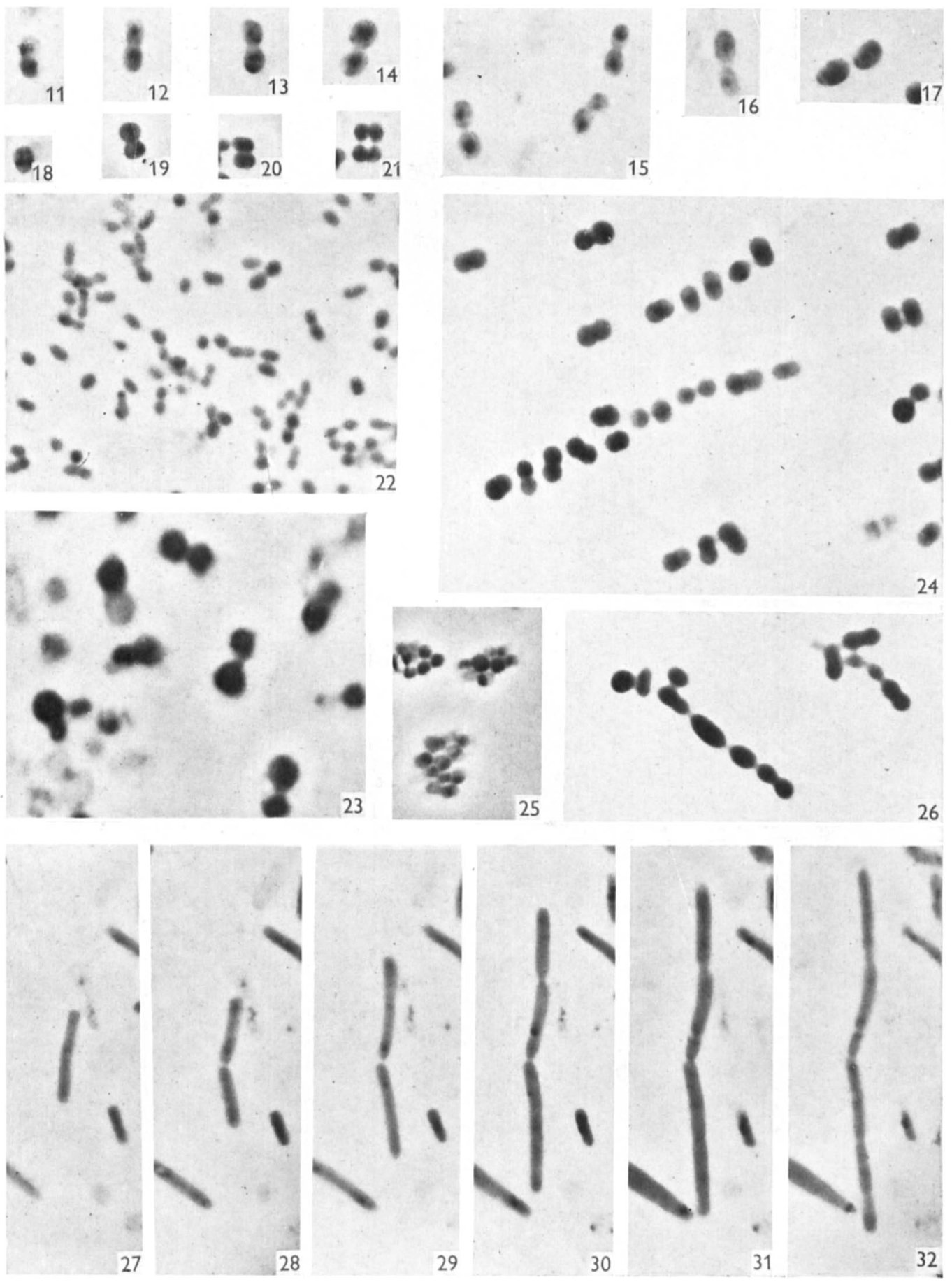

L. F. Hewitt-Bacterial cytology. Plate 2 
Journal of General Microbiology, Vol. 5, No. 2

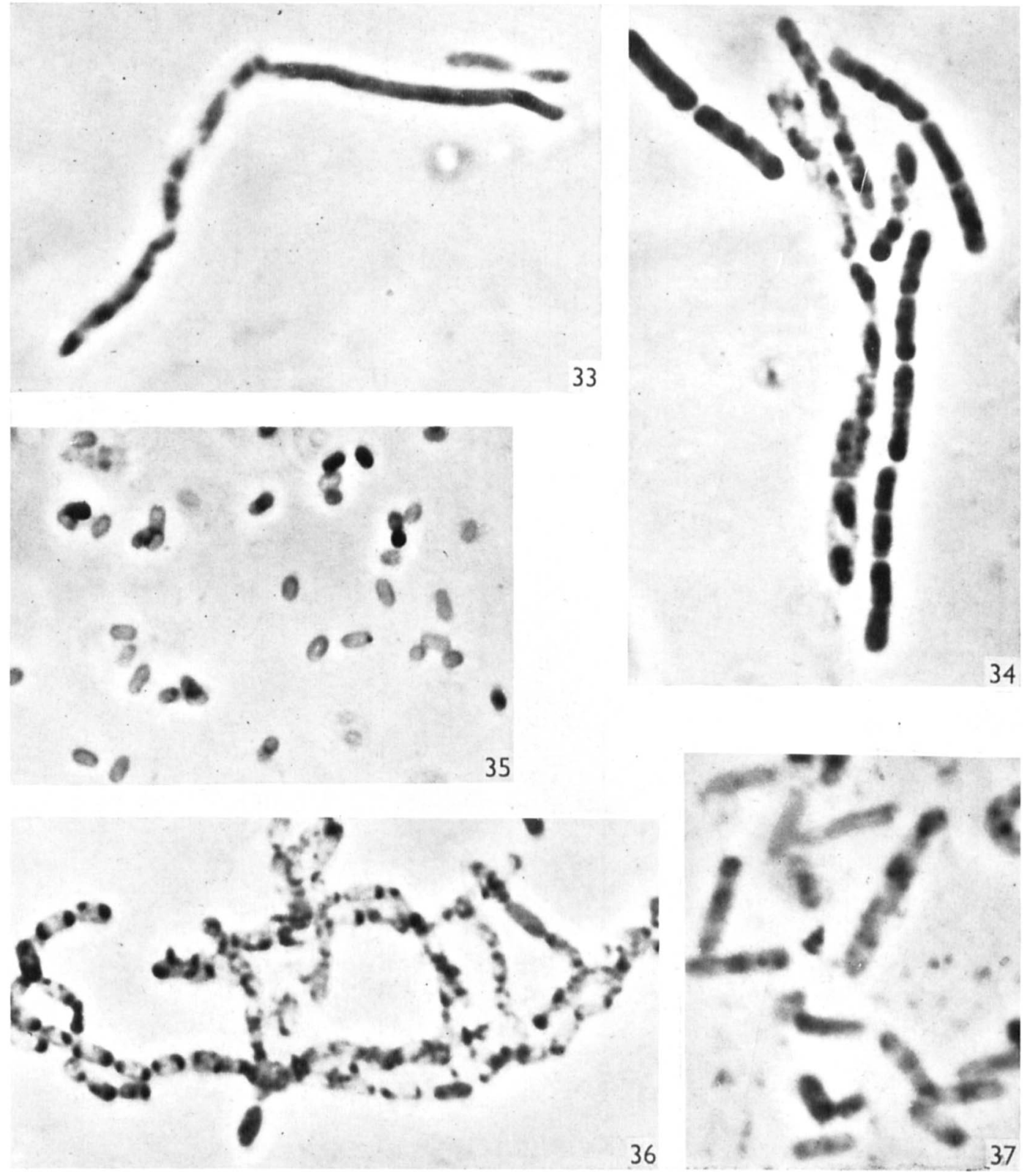

L. F. Hewitt-Bacterial cytology. Plate 3 


\section{REFERENCES}

Badian, J. (1933). Eine cytologische Untersuchung über das Chromatin und den Entwicklungszyklus der Bakterien. Arch. Mikrobiol. 4, 409.

BISSET, K. A. (1950). The Cytology and Life-History of Bacteria. Edinburgh: Livingstone.

Dobell, C. C. (1911). Contributions to the cytology of the bacteria. Quart. J. micr. Sci. 56, 395.

Hewitr, L. F. (1951). Cell structure of C. diphtheriae. J. gen. Microbiol. 5, 287.

Kuteneberger-Nobel, E. (1945). Changes in the nuclear structure of bacteria, particularly during spore formation. J. Hyg., Camb., 44, 99.

Piekarski, G. (1937). Cytologische Untersuchungen an Paratyphus und Colibakterien. Arch. Mikrobiol. 8, 428.

Robinow, C. F. (1942). A study of the nuclear apparatus of bacteria. Proc. Roy. Soc. B, 130, 299.

Schaudinn, F. (1902). Beiträge zur Kenntnis der Bakterien und verwandter Organismen. Arch. Protistenk. 1, 306.

STILle, B. (1937). Zytologische Untersuchungen an Bakterien mit Hilfe der Feulgenschen Nuklealreaktion. Arch. Mikrobiol. 8, 125.

Webs, M. (1949). The influence of magnesium on cell division. 2. The effect of magnesium on the growth and cell division of various bacterial species in complex media. J. gen. Microbiol. 3, 410.

\section{EXPLANATION OF PLATES}

(All are phase-contrast photographs of living cells except figs. 6 and 7.)

\section{Plate 1}

Figs. 1, 2. Bacillus cereus from magnesium-deficient media; note filaments and abundance of transparent cells; $\times 3500$.

Figs. 3-5. B. cereus grown with adequate magnesium content in medium; no filaments, note arrangements of spherical refractile bodies; $\times 3500$.

Figs. 6, 7. B. cereus, fixed osmic acid, hydrolysed with hydrochloric acid and stained with Giemsa. Fig. 6 is a phase-contrast photograph and fig. 7 with ordinary microscope. Dark granules in phase-contrast appear light and unstained in ordinary microscope; $\times 4000$.

Figs. 8-10. B. cereus grown in selenite medium. Figs. 8 and $9, \times 3500$. Fig. $10, \times 2000$.

\section{Prate 2}

Figs. 11-17. Mode of division of a Gram-positive coccus. Note central refractile body; $\times 3500$.

Figs. 18-21. Mode of division in tetrads, note cross-septa; $\times \mathbf{3 5 0 0}$.

Figs. 22-23. Haemophilus pertussis; $\times 3500$.

Fig. 24. Mode of division of a diplococcus; $\times \mathbf{3 5 0 0}$.

Fig. 25. Staphylococcus; $\times 3000$.

Fig. 26. Haemolytic Streptococcus; $\times \mathbf{3 5 0 0}$.

Figs. 27-32. Serial photographs showing multiplication of Bacillus cereus; $\times 3500$.

Plate 3

Figs. 33-34. Gram-positive bacillus. Fig. 33 from broth, fig. 34 from agar plate. Highly refractile structures in cells; $\times \mathbf{3 5 0 0}$.

Figs. 35-36. Pasteurella pseudotuberculosis. Fig. 35 from agar plate, fig. 36 from broth; $\times 3500$.

Fig. 37. Corynebacterium fascians from selenite medium; $\times \mathbf{3 5 0 0}$.

(Received 16 June 1950) 